DOI https://doi.org/10.18551/rjoas.2018-09.05

\title{
BUREAUCRACY AND DISRUPTION REFORM POLICY
}

\author{
Sunarya Aris, Lecturer \\ Faculty of Administrative Science, University of Unitomo, Surabaya, Indonesia \\ E-mail: editriswanto62@gmail.com
}

\begin{abstract}
Indonesian bureaucracy is facing problems and challenges that are very serious in the midst of a very fast and unpredictable flow of change. The emergence of the era of disruption has broad implications for the order of life in the community, the private world and the government bureaucracy. Efforts to accelerate bureaucratic reform will face obstacles, if the behavior and culture of the bureaucratic apparatus do not change for the better; feeling safe and comfortable in a stable position. What is needed now is the ability to see developments far ahead, to respond to it quickly, to dare to act for a breakthrough (innovation), and to take risks to dismantle the paradigm of the past to be faster, more efficient, smarter, more accurate and more useful in service.
\end{abstract}

\section{KEY WORDS}

Bureaucratic reform, public policy, innovation, disruption.

"We live at a time of great change, a time in a new beginning. We live at a time when things start to end". It is one of the views stated by John Naisbitt in his book "Global Paradox', which became a best seller in the early 1990s. Two decades later, the founder of the House of Change, as well as a Professor of the Faculty of Economics and Business at the University of Indonesia, Rhenald Kasali, wrote the book "DISRUPTION: Nothing Cannot Be Changed Before Facing Enough Motivation" (2017), stating that we are currently entering an "end of time". It is not the end of time in the sense of apocalypse, but it means we have entered a new era, namely a digital age, or also called the era of disruption.

The arrival of this new era is marked by the rapid progress of information technology, the emergence of new generations and new entrepreneurs with their breakthroughs. The new generation is called "Millennials", which is very connected to the internet and social media (gadget mindset), and is very different from its predecessor in various ways. This generation prioritizes freedom above all, does not like competition, but prefers to collaborate. This generation is recognized from the disruption they do to and their impact on the business world. The pre-existing business managers begin to fear the work of millennials, because their products/services would be able to take over businesses managed by conventional companies, such as those experienced by the online transportation industry (Grab, Uber, Gojek), hospitality (Airbnb), Tokopedia, Financial Technology (FinTech), and others.

For those who do not immediately realize the changing times will be trapped in the past, feel anxious, and insist on being resistant to changes that cannot be resisted. This new era is called the Disruption era which is characterized by things getting simpler (easier), cheaper (cheaper), accesible (more affordable), and faster (faster). Business competition tends to face unseen opponents, making it more difficult for business people to do their business because they are required to innovate to not only compete with products, but also competes in business models. The death of large companies, such as Kodak, Nokia, and a number of giant retailers at home and abroad is not because of the decline in purchasing power, but because of the era of disruption (Renald Kasali, 2017).

The 7th Indonesian President Joko Widodo (Jokowi), despite not using the term disruption, but in various contexts has admitted that the era of disruption was indeed happening and had to be anticipated. The President stated that today the world is entering the 4th industrial era, triggered by the rapid advancement of information and telecommunications technology which affects various aspects of life. In an era like this, according to the President, it is not the strong country that defeats the weak country, not the 
big one defeating the small one, but rather, the fast one defeating the weak one. At present there are 42 thousand regulations that complicate and ensnare ourselves, are not flexible and will not make us able to compete with other countries. The world has changed rapidly, while we still are working monotonously, do not want to change, do not want to innovate. When we are still learning the internet, other countries are already using mobile internet and smart-office. While other countries have all gone paperless/digital, our State Civil Servants spend more of their daily time making pages of printed reporting documents. When other countries have been talking Tesla mobile, hyperload, managing the outer space for humans, we are still struggling with unproductive problems such as, strikes and rallies, slander, blasphemy, and hoaxes (collected from various online media sources).

In the opening ceremony of the 2018 National Development Planning Conference at the Grand Sahid Jaya Hotel in Jakarta, President Jokowi reiterated that our number 1 enemy is the habit of wasting time. How expensive is the time wasted because the way our bureaucracy is working is still beating around the bush, the work process is still complicated, and the chain of bureaucracy and licensing always takes too long to complete, while with the development of information technology that is making everything easier now, our productivity should have increased. Unfortunately, it is not easy to realize it, because the mindset has not changed. If this condition continued, we can forget about moving forward (Mediaindonesia.com, 20/04/2018).

It was not only once or twice that President Jokowi repeated his strong statement about the performance of the slow bureaucracy. Considering the period of Jokowi-JK administration will end in 2019, it means that it would be very difficult for him to turn Indonesian bureaucracy the way he has expected since there is only one year left (unless elected for the second time). There are still a lot of bureaucratic issues that must be addressed; not just about the technical, systemic and complicated administrative procedures, but also changes in the behavior, mindset and culture of bureaucratic officials who still subscribe to 'zaman old' practices - being in a comfort zone and not willing to change to 'zaman now' way of working. This, at the same time, proves that the agenda of 'mental revolution' which Jokowi-JK have stated in Nawacita can be considered as not achieving the expected results.

This paper elaborates the relationship between bureaucratic reform policy and disruption, which is now a contemporary phenomenon.

Understanding the basic concepts of disruption. Lately, we hear and read the term disruption more often in both conventional and digital mass media. In fact, if we google the keyword "disruption concept", then within 0.34 seconds, Google will manage to display 88,500 results. Several seminars and public discussions have been held by private and government parties that link disruption to various contextual themes.

The growing popularity of the term disruption in public discourse cannot be separated from the publication of the book "Disruption" by Renald Kasali which discusses Disruption by taking case studies at home and abroad. Tracing its history, the term disruption itself was first introduced by Clayton M. Christensen and Joseph Bower in their writing entitled 'The Disruptive Innovation' which was published in the Harvard Business Review Journal (1995). The article was actually intended for executives who determine funding and purchases in a company related to future earnings. Then in his book 'The Innovator's Dilemma', Christensen introduced the Disruptive Innovation Model. Simply put, the basic concept of Disruptive Innovation is an innovation that helps create a new market, disrupt or damage an existing market, and ultimately replace the previous technology. Disruptive innovation develops a product or service in a way that is not predictable, generally by creating different types of consumers in new markets and lowering prices in pre-existing markets. Disruption is a process that continues to repeat itself, and with the advancement of information technology that is accelerating, the process of change is increasingly fast and unpredictable.

Renald Kasali in his book 'Disruption' explores the theory of Clayton M. Christensen by taking the example of recent cases, both in the business field and in the government and social bureaucracy. What does disruption mean? According to Kasali Renald, disruption can be translated as a disturbance, troublemaker, or culprit. When connected with digital words, it means something that comes after the digital era and disrupts the stability of businesses that 
do not use internet and digital technology as their added value. Disruption as an innovation, will replace the entire old system in new ways. Disruption will replace the old, all-physical technology with digital technology that produces something that is truly new and more efficient, also more useful. Or in other words, disruption changes the old way to become more current, practical, simple, effective, efficient and able to adapt to changing times.

In the 15th chapter of the book Disruption: "No Ordinary Disruption", Renald Kasali explains that there is now an unusual process of disruption (no ordinary), even complicated that makes many people anxious if they are too long handled by people who are only capable of making discourses. The development of information technology has broad implications on various aspects of life: (a) technology has connected all people around the world with extraordinary speed (early great disruption), (b) changes are no longer exponential, but linear. It used to be 38 years for radio to reach 50 million users, now it only takes 3 years for the internet, 1 year for Facebook and 9 months for Twitter, (c) the speed of spreading news in seconds, causes most people to move most of their activities, change the way they predict public action, (d) robots make everything automatic, and thus threatens the working class, and (e) money is no longer visible, only virtual records in the digital world.

The strategy to face the era of disruption is to conduct self-disruption by looking far ahead and bravely dismantling old ways. To see changes in the future requires the ability to look forward (visionary), but unfortunately the changes that will occur in the future are something that is not easy to see and read. After seeing it, the next step is moving and solving the problem. The task of the leader is to make what he sees is also seen by his subordinates, then moves them to complete the changes thoroughly. Three things are suggested, namely:

First, do not be comfortable being a "Winner". An organization that has long been established may seem that it no longer needs to make many innovations. The feeling of security that arises is due to the assumption that the customer will continue to be loyal. Whereas in reality, the shift in the consumer segment (from the previous Generation $X$ to Millennials) requires the development of various aspects, including services.

Second, do not be afraid to cannibalize our own product. Learning from Kodak's bankruptcy case, an organization should always carry out innovations. Including having the courage to become cannibals for their own products. This is a proactive step before other parties do. In the Kodak case, they feel that their expertise in negative film providers will not be eroded by technology. Whereas on the contrary, the presence of a digital camera actually forces Kodak have to go out of business.

Third, reshape or create a new one. In the era of disruption, there are two choices that can be taken, namely to reshape or create, or choose both. When deciding to reshape, it can come from innovating the product or service that are already owned. Meanwhile, if you choose create, you have to be brave to have innovations that are in accordance with consumer habits. If you can "read" the situation well then see the opportunities that exist, that's how you can survive in an era of disruption.

Meanwhile, the characteristics of officials/leaders needed in the era of disruption are: (a) self-disciplined, (b) risk taker, (c) have the ability to simplify, (d) have mindset growth, (e) have assertive communication skill, (f) have broad and wise perspectives, (g) have the ability to think critically, and (h) have the ability to think creatively (Renald Kasali, 2017).

In his writing "Straightening the Understanding of Disruption" which was published in Kompas online (Kompas.com, 05/05/2017), Renald Kasali redirected various views which he considered inappropriate in interpreting disruption, because there are still many who think that disruption is only related to information and communication technology alone, or more specifically about online transportation (Grab, Uber, GoJek), or disruption means only the issues of business application, or a start-up business, and some even think that disruption is just a matter of online services. Understanding that disruption only occurs in the digital industry, according to him is clearly not right, because disruption occurs everywhere, in any industry, even in government bureaucracy. Disruption has even changed the relationship base from individual ownership to collaborative collective. Disruption is not just a phenomenon today, but the phenomenon of tomorrow (the future) brought by the reformers 
to the present. To provide a more accurate understanding, Renald Kasali identified the characteristics of disruption as follows:

- Disruption results in saving a lot of costs through business processes that become simpler;

- Disruption makes any quality it produces better than the previous one. If it is worse, then it obviously is not disruption;

- Disruption has the potential to create new markets, or make those who have been excluded become included. Making a market that has been closed open;

- Products/services resulting from disruption must be more easily accessed or reached by its users. Like online taxi or taxi services, or banking services and including financial technology, everything is now available in the hand, on our smartphones;

- Disruption makes everything now smarter, more time-saving and more accurate.

Current Indonesian Bureaucracy Situation. President Joko Widodo's (Jokowi) to-thepoint statement on the introduction of this paper complaining about the condition of the Indonesian bureaucracy is not only discourse-like or rhetoric, but it is true. This can be evidenced by empirical facts from various research results that Indonesian bureaucracy is still lagging behind with other countries, including neighboring countries. The 2017-2018 Global Competitiveness Report released by the World Economic Forum (WEF) in 2018 reduced Indonesia's competitiveness rating from 37th position in 2016 to 41st 2017. Indonesia is only superior to the Philippines (57), Vietnam (60), and Laos (93). Some of the fundamental problems in the Indonesian bureaucracy that got the spotlight from the World Economic Forum (WEF) included corruption, which ranked first with 13.8 score, government bureaucracy inefficiencies (11.1), infrastructure limitations (9.2), access to finance (8.8), inflation (8.6), political instability (6.5), poor work ethic (5.8), tax rate (5.2), limited educated human resources (4.3), regulation taxation (4.8), currency regulation (4.6), government instability (4.0), poor people's health (4.0), theft (4.0), lack of innovation (2.5), and policies inhibiting labor (4.0) (https://www.weforum.org,17/01/2018).

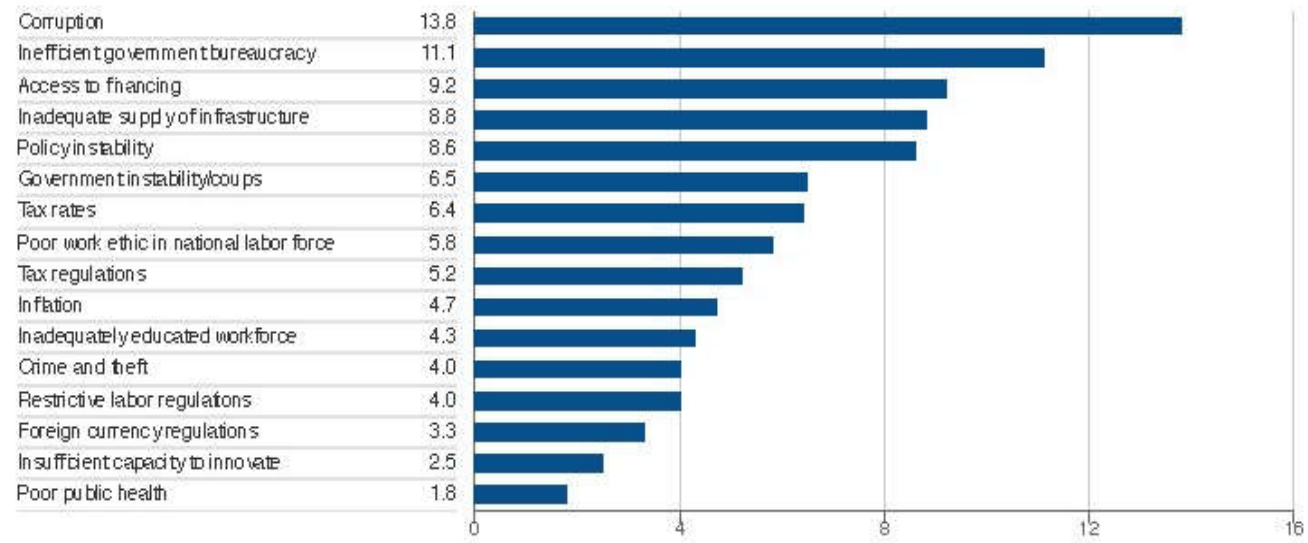

Source: World Economic Forum (WEF, 2018).

Figure 1 - Most problematic factors for doing business

The findings of the World Economic Forum (WEF) are almost the same as the results of the Kompas R \& D Survey (September 2016) carried out in 14 major cities in Indonesia that place the problem of corruption and complicated bureaucracy (bureaucratic inefficiency) as the main problem still faced by the bureaucracy in Indonesia up to now.

Meanwhile, KemePAN-RB dated January 24, 2018 released the results of the 2017 Provincial/District/City Government Public Service Performance Evaluation, as the implementation of Article 7 paragraph (3) point c, Law Number 25 of 2009 concerning Public Services which states that the Minister responsible for the use of the state apparatus is tasked with monitoring and evaluating the performance of public service delivery. The results of the 2017 Public Service Performance Evaluation is shown in the graph below: 


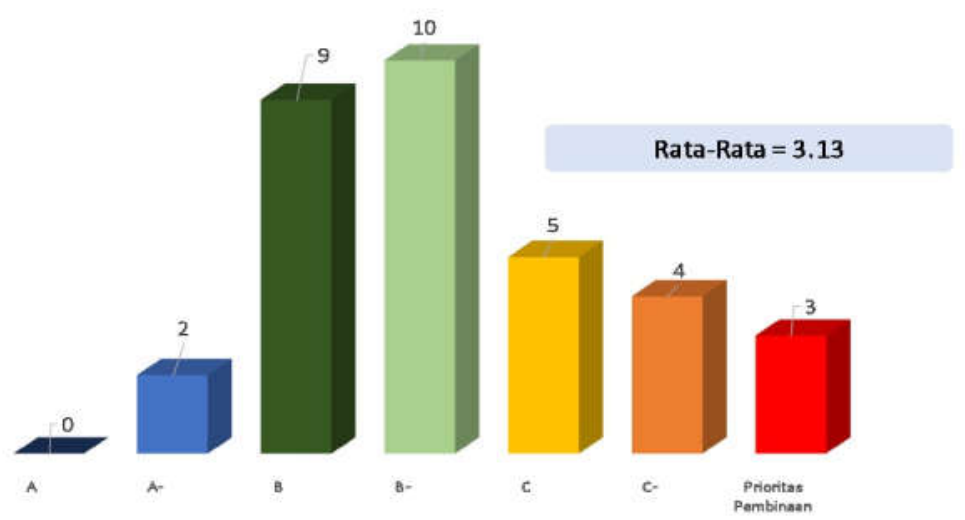

Result of 2017 Provincial Government Public Service Performance Evaluation

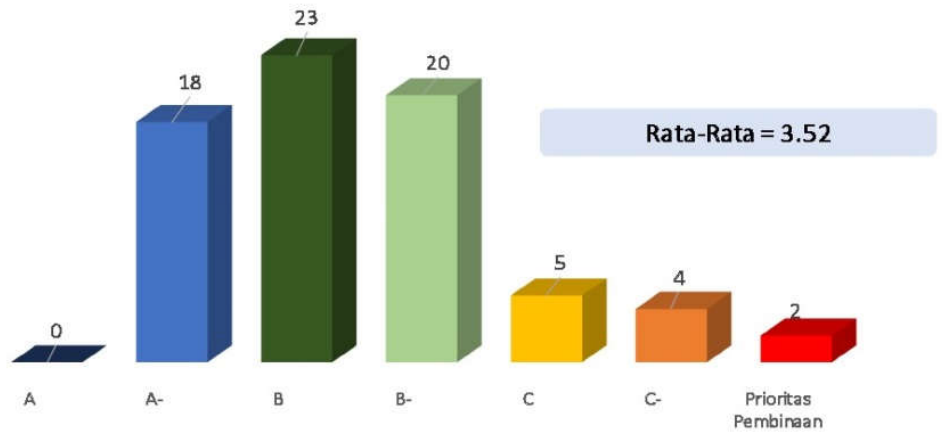

Result of 2017 District/City Government Public Service Performance Evaluation

Figure 2 - Public Service Performance Evaluation (Source: KemenPAN-RB, 2018)

The graph above shows that only 2 provinces received the Very Good (A-) ranking from 34 existing provinces, namely DKI Jakarta Province and Riau Province. Meanwhile, for districts/cities, there are 18 of them which obtained the title of Very Good (A-). Interestingly, there are still 3 provinces and 2 regencies/cities that are "lacking" with no ranking (guidance priorities are needed). This condition is very ironic, because even though bureaucracy reformation has been implemented for decades, especially in the public service sector, there are still regional governments that have not progressed/changed performance. So, what have regional government officials done so far to serve the people in the area?

The bureaucracy problem above correlates with the findings of the State Ombudsman which reported that during 2017 there were 7,999 reports from the public about misadministered procedures carried out by ASN at the central and regional levels. The top five types of mis-administration are: (a) procedure deviations $(1,714)$, (b) not providing services $(1,355),(c)$ incompetent on receiving complaints (802), (e) abuse of authority (666), and (f) money, goods and services requests as rewards (605) (Kompas.com 29/12/2017).

Some of the findings about the bureaucratic conditions above reinforce the argument that bureaucratic reform policies including the implementation of public services have shown changes, but in various aspects harder work is needed to improve. Two of the most crucial aspects are corruption and bureaucratic inefficiency. This fact also proves that Indonesian bureaucracy is still unable to fully respond to the demands and expectations of society and adapt to the global environment that is changing very rapidly.

This condition was acknowledged by the Minister of State Apparatus Empowerment and Bureaucratic Reform, Asman Abnur, that Indonesia faces difficult challenges. The first is about how to gain public trust by convincing the people of changes that can be made by the government. This becomes very important considering the people's trust is the basic capital of development. Second is about how the country can improve competitiveness among 
countries in the world so that it has an impact on increasing the ability of the state to provide welfare for the community (Kompas.com, 08/02/2017).

Bureaucracy and Disruption Reform Policy. What is bureaucratic policy reform? It is related to government policy or state policy which is also called public policy (public policy), meaning a series of actions that is established and implemented or not implemented by the government which has a purpose or is oriented towards a specific goal for the benefit of the whole community (Irfan Islamy, 1997). Whereas, bureaucratic reform is interpreted as an effort to make fundamental reforms or changes to governance in various aspects, such as legislation, institutions, business processes and human resources in order to realize good governance and corruption-free (clean governance) (KemenPAN-RB, 2014). So, a bureaucratic reform policy can be briefly translated as a government policy that aims to reform fundamentally (various) aspects of the administration of general government and especially public services. If bureaucratic reform policy is linked to disruption, then its understanding becomes a policy reform that is able to respond and adapt to the dynamics of strategic environmental changes triggered by the rapid development of information technology and the increasing demands of society to realize a modern bureaucracy (worldclass bureaucracy).

Bureaucratic renewal policy is basically carried out in every period of government even though it uses different terms. Even since Indonesia's independence (Old Order) day, continued to the New Order period, and gained momentum in the reform era of 1998. Since the reform era, the government has issued various policies as a legal basis for the implementation of reformation, including: (a) The Law No. 25 of 2009 on Public Services, (b) Government Regulation No. 96 of 2012 on Implementation Instruction of Law No. 25 of 2009 on Public Services, (c) Presidential Regulation No. 81 of 2010 on Grand Design of Bureaucratic Reform for 2010-2025, and (d) Regulation of Minister of State Apparatus Empowerment and Bureaucratic Reform No. 20 of 2010 on Road Map of Bureaucratic Reform for 2010-2014, and other relevant regulations, with three main objectives: (a) the realization of a clean and corruption-free government, (b) improvement of the quality of public services, and (c) increase of the capacity and accountability of bureaucratic performance, with the ultimate goal of creating a clean, competent and serviceable bureaucracy.

Additionally, the government also issued several policies to strengthen and accelerate bureaucratic reform, including:

- From the institutional aspect, the government has issued Government Regulation No. 18 of 2016 on Regional Instruments, which regulates the establishment, type and criteria of regional instruments, as mandated in Law Number 23 of 2014 on Regional Government.

- From the aspect of government administration, there has been an order issuing Law Number 30 of 2014 on Government Administration. This policy provides an opportunity for ASN officials to carry out discretion and innovation when there is a regulatory vacuum.

- From the aspect of the management of the State Civil Apparatus, the government issued Law No. 5 of 2014 on the State Spil Apparatus. This policy mandates the establishment of a non-structural institution, the State Civil Apparatus Commission (KASN), which aims to ensure the recruitment of merit-based ASN-based officials based on competency in order to realize the right men in the right place.

- From the aspect of work management and service behavior, the government has issued Presidential Instruction No. 12 of 2016 on the National Movement for Mental Revolution. This policy placed the PANRB Minister as the implementing coordinator focused on enhancing ASN's HR capacity, improving enforcement of the Apparatus discipline, improving service standards and innovative service systems (egovernment), improving the performance of management system and improving public service behavior which is expected to be fast, transparent, accountable, and responsive.

- To evaluate the performance of bureaucratic reform, the government has issued 
PermenPAN-RB No. 14 of 2014 on Guidelines for Evaluating Bureaucratic Reform of Government Agencies.

- For the preparation of community satisfaction surveys, the government has issued KepmenPAN-RB Number 14 of 2017 on Guidelines for Preparing the Community Satisfaction Survey for Public Service Providers.

- For the use of Social Media (Social Media), the government has issued PermenPANRB Number 83 of 2012 on Guidelines for Utilizing Social Media of Government Agencies.

- To encourage the acceleration of public service innovation, the government has organized a Public Service Innovation Competition (KIPP) by requiring every Ministry/Institution and Regional Government to create at least 1 (one) innovation every year known as one agency one innovation. This policy is outlined in PermenPAN-RB Number 30 of 2014 on Guidelines for Public Service Innovation.

- To eradicate illegal levies, the government has issued Presidential Decree Number 87 of 2016 on the Task Force for Clearing Illegal Levies (Illegal Levies Siber). The job is to eradicate illegal levies by optimizing the utilization of personnel, work units and infrastructure, both in the ministries / institutions and regional governments.

- To provide convenience and affordability of public services, the government has issued PermenPAN-RB No. 23 of 2017 on the Implementation of Public Service Malls (MPP). This policy aims to provide convenience, speed, affordability, security and comfort to the public in obtaining services, and improve global competitiveness in providing ease of business.

- For ease of effort (Ease of Doing Business, EoDB), the government has issued dozens of economic policy packages in order to simplify and cut the long and complicated licensing chain, by applying the principle of HGSL (delete, merge, simplify, bestow).

The list of policies above will be even longer if it is associated with the elaboration of policies issued by Ministries/Institutions and Regional Governments (Provinces/Regencies/Cities), in the form of Ministerial Regulations, Institutions, Regional Regulations, Governor Regulations and Regulations of Regents/Mayors throughout Indonesia. So, considering the aspects and scope, the bureaucracy reform policy is actually quite complete, including the measurement instruments.

The question is: why is the implementation of bureaucratic reform still running slowly? Here are some critical notes to answer this question.

Policies are less responsive and adaptive to changing times. Every policy made by the government, whatever its form, aims to respond to changing times in order to ensure the creation of security, order, order, peace, harmony, rights and obligations in the order of life of the nation and state within the framework of the Republic of Indonesia (NKRI) and participate in maintaining world peace based on Pancasila, the 1945 Constitution and Unity in Diversity. So, the policy is made at a certain time, for certain purposes that apply as long as the policy is not revoked by a new policy or aborted by the Constitutional Court because there are parties who filed a judicial review.

The problem is, the fast changing times are very difficult to predict, causing policies to become less relevant to developments. Actually the solution is easy, change immediately with a new policy when the situation requires, then the problem is solved. But in practice, it's not that easy. Moreover, the policy is in the form of a Law (UU) or Regional Regulation (Perda), because these two government policies must be formulated and approved by the legislature (Houses of Representatives). In reality, formulating a law or regional regulation requires a long and winding time, an unavoidable pull of interests and political lobbies which causes the delay on when the law or regulation should be passed. Even in some cases that surfaced to the public, the process of making laws or regional regulations had occurred acts of corruption and collusion between executive officials and the legislature. Articles and paragraphs and the ratification of regulations become commodities that can be traded 
(transactional) which have high value. As a result, there is a legal vacuum that narrows and inhibits the movement of the apparatus as implementing the policy (implementor).

The performance of lawmakers is also often questioned by the public, because their performance has been declining from time to time. According to a study by the Indonesian Parliamentary Community Concern Forum (Formappi) the performance of the House of Representative members in the field of legislation (law making) is very low. This can be seen until the end of the 2017 session; the legislative body only ratifies 6 Priority Draft Laws (RUU), whereas there are 52 bills that are included in the priority national legislation program. In addition to the 6 laws, there are 11 laws that were also passed by the House of Representatives, but the Law includes open cumulative categories, such as international conventions, budget Laws, and Government Regulations Substituting Laws (Perppu). The category law does not require design or discussion so that the approval process is faster. For comparison, in 2015 and 2016, the House of Representatives each passed 3 laws from 10 priority draft bills (BBC Indonesia, 21/12/2017).

Another problem is the limited ability or competency of lawmakers or regional regulations makers, both the executive and legislative bodies, in foreseeing further progress so that they can be anticipated in the laws or regulations that are being made. In the era of disruption like now this capability becomes very important, so that the resulting policies are not quickly outdated (expired).

A real example to provide an overview of the problem is Law Number 22 of 2009 on Road Traffic and Transportation. When formulating this law, none of the legislators were able to imagine that 8-9 years later there would be online-based public transportation (Grab, Uber and GoJek). As a result, there is no single article and paragraph in the Law that regulates it. Why the law is not immediately changed? Because, as described above, the problem of making or changing the law is not easy, it takes a long process. The short cut is to take the Regulation of the Minister of Transportation and the National Chief of Police Department as the legal basis, so that online-based transportation is not considered illegal.

Implementation of policies: Synergy and Egocentric. Many parties argue that one of the causes of the slow performance of the Indonesian bureaucracy is due to the lack of synergy between policy implementers, both between the Ministry and Institutions in the center and between the center and the regional government. This is due to several things, including: (a) the existence of sectoral or institutional egos, (b) conflicts of interest, (c) the inability of ASN's HR to implement policies, (d) lack of socialization, and (d) the presence of political economy. According to the Deputy Head of Policy Research at the State Administrative Institution (LAN), there has been no significant change in the bureaucratic reform agenda due to the lack of synergy between existing agencies/ministries/institutions. Bureaucratic reform cannot be done by each institution alone, but rather as a team. Furthermore, it is said that until now each agency is still in the early stages of reforming, far from reaching the targeted output. Since it was first launched in 2010, there are 8 areas of bureaucratic reform that are scheduled by the government, namely institutions, human resources, governance, supervision, service, accountability, regulation, and mindset of the state apparatus. Of these 8 areas, 4 are the most difficult to change, including the mindset aspect, institutions, regulations, and human resource of the apparatus recruited (Tempo.co, 22/08/2017).

According to Professor of Public Administration at the Faculty of Social and Political Sciences, Universitas Gadjah Mada, Wahyudi Kumorotomo, there are still many matters handled by public institutions with a paradigm to make it difficult for service users. Regulations that are under executive control may have begun to improve, but there are still many needs for improvement of regulations under the law that require downsizing, such as HO (Hindrance Ordinance), TDP (Company Registration), Unification of Principle Licenses and Location Permits. Many regions are still fixated on the old regulations on licensing and there is no breakthrough. In some areas, the centralization of matters conducted in UPTSA has increased efficiency and simplified the procedures, but there are regions that have set new types of licenses for the same function. Consequently, although the national level of ease of doing business at the level has improved, in many regions the ranks have worsened. 
What is needed now is a paradigm shift at the level of implementation, not a debate about the paradigm of bureaucratic reform at the concept level (Jawa Pos, 15/12/2017).

The issue of synergy is very important in the implementation of a cross-sectoral policy, in addition to considering the vast geography of Indonesia, and the unequal diversity of its human resources which makes building into the same vision not easy. Therefore, President Joko Widodo, in addition to carrying out activities to various parts of the country, also gathered several regional government leaders (Governors, Regents, Mayors and members of House of Representative) to the Presidential palace to equalize the vision and perceptions in implementing bureaucratic reforms to eliminate sectoral and institutional egos that hinder policies cannot be implemented as well as expected.

Public Service Innovation: Competition and Collaboration. Innovation is the creative process of creating knowledge in making different new discoveries and/or modifying existing ones. Public Service Innovation is a breakthrough type of service, either original creative ideas and/or adaptations/modifications that provide benefits to the community, both directly and indirectly (PermenPAN-RB Number 30 of 2014).

The policy of the Public Service Innovation Competition (KIPP) has been implemented since 2014 with the concept 'one agency one innovation'. This policy is actually a very good policy, and can even be said to be a breakthrough to encourage the acceleration of bureaucratic reform, because this policy is (mandatory) followed by Ministries/Institutions/Local Governments. The objectives are: (a) selecting, documenting, disseminating, and promoting innovation as an effort to accelerate the improvement of the quality of public services, (b) providing appreciation for public service providers whose innovations are designated as Top Public Service Innovations, (c) motivating public service providers to increasing innovation, and professionalism in providing public services, (d) improving the image of public service providers, and (e) being a means of exchanging experiences and learning innovations (KemenPAN-RB, 2018).

Strategies to use include: (a) innovation is included in institution budgets, (b) innovation is part of institution's tasks and functions, (c) innovation has a legal basis, and (d) innovation is used as an organizational culture (Muhamad Imanuddin, 2018). Following are the results of the development of KIPP implementation within 3 years.

Table 1 - Results of the development of KIPP implementation of 2014-2017

\begin{tabular}{|c|c|c|c|c|}
\hline Descriptions & 2014 & 2015 & 2016 & 2017 \\
\hline Registered innovations & 515 & 1.189 & 2.476 & 3.054 \\
\hline $\begin{array}{l}\text { Stage Result: } \\
\text { Desk Evaluation }\end{array}$ & Top 99 & Top 99 & Top 99 & Top 99 \\
\hline $\begin{array}{ll}\text { Stage Result: } \\
\text { - } \\
\quad \text { Intesentation and } \\
\text { - } \quad \text { Field Verification }\end{array}$ & Top 9 & Top 25 & Top 35 & Top 40 \\
\hline
\end{tabular}

Source: Muhamad Imanuddin (2018).

KIPP's policy is very relevant in the current era of disruption, to encourage or even force all institutions to make breakthroughs or innovations in their respective area, while at the same time changing the passive/monotonous and slow bureaucracy culture to be creative and move dynamical so that it can be adaptive and responsive to the changes that occur. But based on experience, because the author has also been involved in this competition, there are several notes that need to be considered in the future.

First, innovation is the result of creative ideas to respond to the demands of society and changes in the environment. It takes people who have sufficient competence to create creative ideas, and translate them into a proposal within the format, system, number of words 
and weight of assessment that have been determined by the organizer (KemenPAN-RB) before registering it online to sinovik.menpan.go.id.

The problem that arises at this stage is the limited human resources to develop very clear proposals. More often than not, institutions having creative and innovative ideas are not able to pour them well into a good proposal document. As a result, their proposals are eliminated at the Desk Evaluation stage. The solution is to use consulting services with the consequence of additional costs. HR competency ASN is again at stake when passing the Desk Evaluation stage to the next stage, namely the presentation and interview stages. If there is a good possibility of innovation in the proposal, but the people tasked to present and answer questions from the jury do not master the skills, they will be eliminated at this stage.

Second, this innovation is contested (competition), putting winners into the Top category, but the fact is there are more people who do not win (lose). This can be proven by comparing the number of innovations registeres to the number of innovations that get the Top title as shown in the table above.

In this context, there are two questions that must be answered: (a) for innovations that do not win or lose in the competition. Can these innovations be implemented to improve the performance of the institution or be simply thrown away, because they are considered losing (not innovative), even though they may still be useful for the institution, (b) for innovations that get the Top title. Is there a guarantee that the innovation will be implemented continuously in the institution? Because innovation needs to be developed and adapted to developments, especially the technology-intensive ones. Based on experience, not all innovations that fall into the Top category can be carried out consistently in the relevant institution. There are several factors, including: (a) lack of maintenance and development, (b) new regional leaders or agencies who consider innovations made by previous leaders not the results of their work, which in would make the innovation be used in vain.

Third, in the future it will be necessary to consider increasing the value and benefits of implementing public service innovations, namely: (a) the need for monitoring and evaluation of innovations that have been awarded Top Category. If not implemented, the Top ranking may be revoked, and transferred to similar institutions in other areas, (b) the need to change the approach, from competition to collaboration, and/or merge the two approaches, aiming to make the innovations that have been created, whether the ones receiving the title of Top Category and those that fail to, to be used to improve service performance, and (c) the change in approach from competition to collaboration requires a more in-depth study, because the problems faced are not easy. But if successful, most of the innovations made by Ministries/Institutions/Local Governments will be utilized to its maximum potential.

Information Technology Infrastructure: Limitation and Self-Disruption. The acceleration of bureaucratic reform is almost impossible without utilizing information technology. So, it needs not only the availability of Human Resources who are sufficient and competent in the field of IT, but also the availability of reliable and evenly distributed IT infrastructure throughout the country. This is a big challenge for the government if it wants to implement egovernance or smart governance, smart city or smart office or whatever term is used, which aims to integrate data and information in real time.

In some areas, especially in big cities, infrastructure technology might be very adequate. However, in other areas, it is not uncommon for people to have to climb the hills just to get mobile services, sometimes they might even need to climb trees. Running an internet-based application for public services demands speed and stability of internet access. Another crucial problem is that electricity is not always accesible in some regions. Even if it is available, there is no guarantee that people can rely on it for 24 hours. Without the availability of electricity, then any sophisticated device and application used will be in vain.

Cooperation with other countries that have succeeded in implementing e-government is also very much needed, such as South Korea which has succeeded in developing mobile government (m-gov). The results of the research by Prof. Kyoung Yul Bae (2011) shows that South Korea has consistently developed e-gov since the 1980s. Continuous development is carried out to adapt to technological progress. Now the South Korean government has been able to implement mobile government ( $\mathrm{m}-\mathrm{Gov}$ ) by utilizing wireless-based communication 
technology in the administration of government. M-Gov did not replace e-Gov, but rather it improves e-Gov to be accesible through cellphones, Personal Digital Assistants (PDAs), WiFi devices, and mobile networks.

On April 18, 2018, President Jokowi led a Limited Meeting in Bogor to discuss the acceleration of reforms in the field of business licensing and plans to implement an integrated online licensing system called Online Single Submission (OSS). The plan is for the government to issue Presidential Instruction or Presidential Regulation to force all ministries, institutions and regional governments throughout Indonesia to simultaneously implement OSS, without waiting for the readiness of the local government. Conceptually, OSS is considered as a large-scale change to make all permits from the center to integrated areas become a single unit, so that licensing arrangements can be completed faster. Its other objective is to change the bureaucratic culture and eliminate sectoral egos (Tempo.co, 18/04/2018).

The idea of implementing OSS is very good, and it should have been implemented since a long time ago. President Jokowi has dared to conduct self-disruption by looking at the challenges that might be faced by the government in the future and to dismantle the old ways, despite dealing with bureaucratic culture and infrastructure conditions that have not fully supported, let alone the geographical issue of Indonesia, accompanied by the inequality of infrastructure development. This requires high commitment and consistency from government leaders to succeed as expected.

State Civil Apparatus and Officials Recruitment: Competence and Corruption. The State Civil Service (ASN) Human Resources occupies a very important and strategic position in determining the success of the Indonesian bureaucratic reform. This is because ASN is the executor of various policies and the provider of services to the community. ASN is the driving force and agent of bureaucratic change so that it can compete with other nations in the world. So, no matter how well the regulations are made, or how well the system is built, and how sophisticated the technology used is, it all depends on ASN HR, both from the levels of education of the recruited that may influence competence and its distribution between regions and institutions, as well as its management.

The issuance of Law Number 5 of 2014 on State Civil Apparatus (ASN) can be considered as a major reform in the management of the state civil apparatus compared to the previous regulation of Law Number 8 of 1974 on the Principles of Civil Service. There are several new terms contained in this Act, including: State Civil Apparatus (ASN), Civil Servants Employees, (c) Civil Servants (PNS), (d) Government Employees with Employment Agreements (PPPK). In addition, the following naming of types of positions also changed: (a) Administrator Position, (b) Functional Position, and (c) High Leadership Position. The High Leadership Position (JPT) is divided into: (a) Main High Leadership Position (JPTU), (b) Middle High Leadership Position (JPTM), and Primary High Leadership Position (JPTP).

Another new thing is the establishment of a new non-structural institution named the State Civil Apparatus Commission (KASN). His duties are to promote and oversee the implementation of the ASN Basic Values, the implementation of the ASN employee code of ethics and code of conduct, and the implementation of merit systems in ASN policy and management, and maintain the neutrality of ASN employees from political intervention and ASN professional development.

Based on the 2017 KASN report released in January 2018, it can be seen that ASN in Indonesia is the driving force for bureaucratic reform, based on age groups and education, as shown in the graph below.

In its report, KASN also mentions several ASN problems that have the potential to disrupt the acceleration of bureaucratic reform in the future, including: (a) distribution of employees that do not meet needs, where most employees work in urban areas, (b) qualifications and competencies of existing employees do not match as required. At present, the number of administrative staff exceeds the need, while the number of technical staff is still very limited, especially in the expansion area, (c) the quality of the existing staff is still low, and (d) the ratio of ASN to the population is the lowest among neighboring countries $(1,64 \%)$. This low ratio reflects the low ability of the bureaucracy to serve the community, 
while the percentages in neighboring countries are as follows: Singapore (4.0\%), Malaysia (5.0\%), Philippines (2.9\%), and Brunei Darussalam (11.4\%). Other problems as the result of the zero growth policy and moratorium on CPNS acceptance over several years are: (a) aging ASN employees will disrupt the smooth succession of 440,000 ASN leadership positions, (b) "tsunami" threat of retirees because more than $40 \%$ of ASN employees over 51 years old (KASN, 2018).

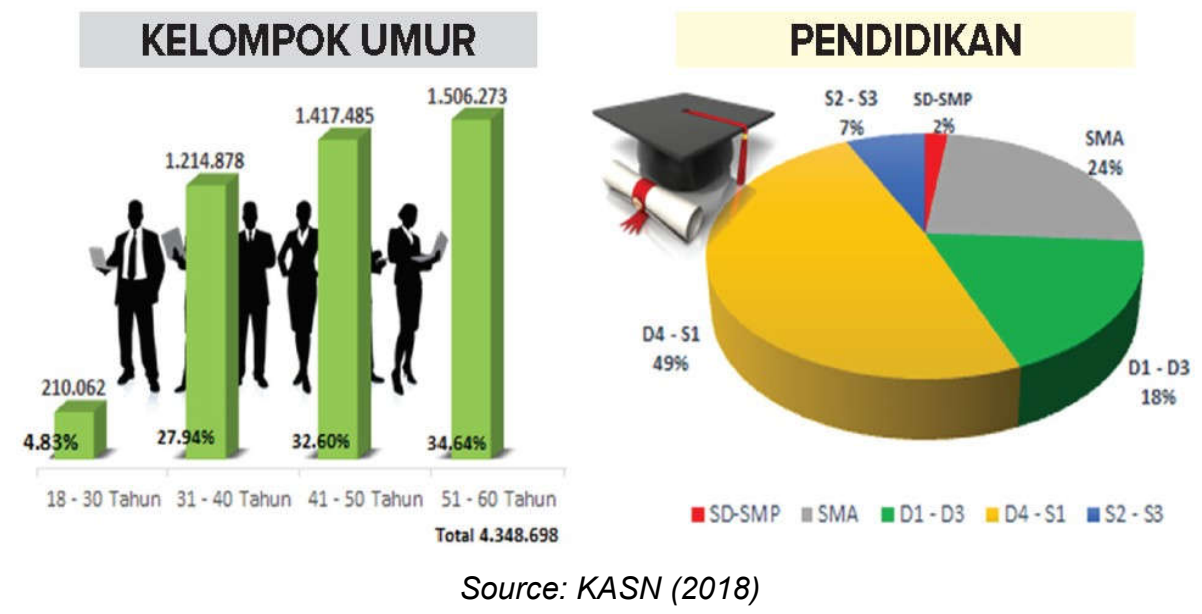

Figure 3 - ASN in Indonesia

Meanwhile, in the implementation of recruitment of officials, especially the High Leadership Officials (JPT), KASN has launched the High Leadership Position Selection (SIJAPTI) application which aims to facilitate the assessment of various parameters measured in the implementation of merit-based high-ranking officials recruitment. During the three years it has been implemented, the results were not very encouraging, even though it had increased. This can be seen from the comparison of the number of KASN recommendations regarding approval, repairs and cancellations/reviews, as shown in the graph below.
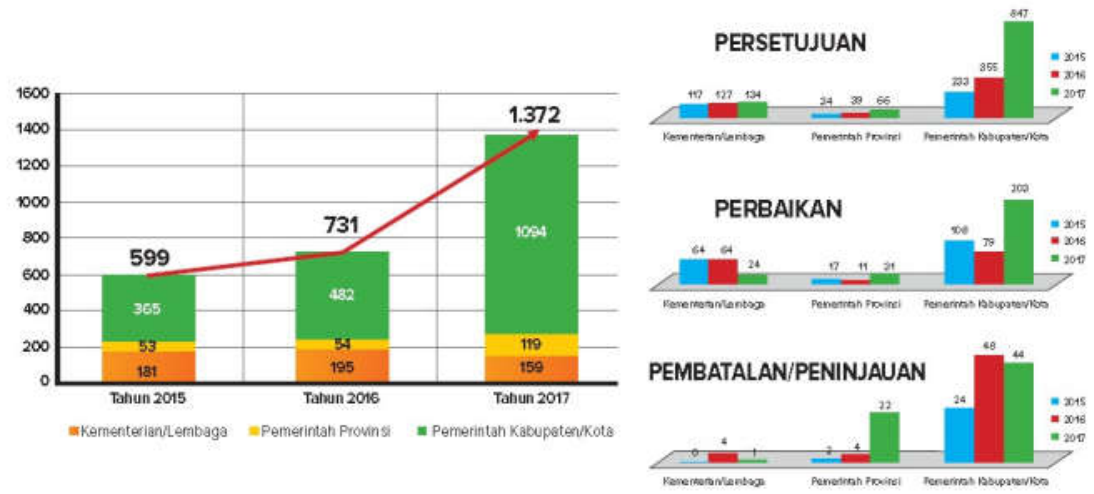

Source: KASN (KASN, 2018)

Figure 4 - KASN Recommendation Development of 2015-2017

Parameters for repairs and cancellations/reviews indicating a still high trend can be interpreted that the recruitment process of high-ranking officials is not in accordance with the competency standards determined by KASN. This can be correlated with several cases that surfaced to the public, where officials recruitment becomes a commodity that can be traded by regional leaders. Some of the On Site Operations (OTT) conducted by KPK are related to the practice of buying and selling official posisitions, such as the case of the Klaten Regent, Nganjuk Regent, and Jombang Regent. This is an iceberg phenomenon, because it is not a 
secret anymore and it has happened everywhere, not only in the three regions mentioned. To occupy a position, there will be some kind of fee requested. The more strategic the position, the higher the cost. This is a classic problem that has not been able to be completely eliminated until now. The recruitment of officials for high-ranking positions then seems only for show, because those who will occupy the positions are not determined by quality (competence), but rather by how much they are willing to pay (bribe).

This kind of practice causes some negative impacts in the long run, including: (a) the quality of officials appointed does not meet the required competency standards (incompetent), and this is one of the causes of the bureaucracy being less responsive and adaptive to changing times, (b) the potential for corruption will be even greater, because those appointed will have to obtain back the costs incurred, so the relevant officials must find a loophole for corruption in his institution, (c) close the opportunity for employees who have competence, but do not have the ability to bribe and/or, despite having high integrity, and (d) damaging the image of the bureaucracy in the eyes of the public, which in turn will lead to increased public distrust of the government. This is a big challenge to improve the bureaucracy in Indonesia in the future.

Closing: Millennials and a New Era of Indonesian Bureaucracy. In the midst of various problems and severe challenges faced by the Indonesian bureaucracy as described above, the question is, is there still an opportunity to improve the bureaucracy, considering the jargon of "World Class Bureaucracy"? There are two possible answers for that: (a) no, there is not (pessimistic), and (b) yes, there is (optimistic). The opportunity is not in reach anymore (pessimistic) because the bureaucracy system now is still run by ASNs who are now approaching retirement (51-60 years) which amounts to 1.5 million (34\%) people of the total ASN available. However, there is still something we can improve (optimistic) if a massive recruitment is carried out to replace retired ASN with a new generation, millennial generation, by tightening the competency-based CPNS recruitment system (by merit), so that the best of our fresh generation will be recruited based on the level education, mastery of information technology, mastery of foreign languages (English), idealism, and integrity and work culture. If this can be done, bureaucracy will surely experience significant changes.

With regard to this matter, on March 27, 2018, KemenPAN-RB along with Ministries and Institutions across fields held a Presidential Lecture for CPNS at Istora Senayan Jakarta with the theme "United in Harmony: Towards a World Class Bureaucracy in 2024". The event aims to improve insight and knowledge and open the perspective of CPNS to understand the challenges of the task in the industrial era 4.0. In addition to debriefing from President Jokowi, other speakers included Minister of Finance Sri Mulyani Indrawati, Head of BPIP (Pancasila Ideology Development Agency) Yudi Latief, and CEO Gojek Nadiem Makarim.

MenpanPAN-RB, Asman Abnur in his report stated that in 2017, selection was made for 37,138 CPNS formations in 62 ministries/institutions and 1 province with a total of over 2.4 million applicants. This number is divided into a general formation $(34,167)$, Cumlaude graduate formation $(2,310)$, disability formation (168), and the formation of youths from Papua and West Papua (493). Full recruitment used a Computer Assisted Test (CAT) system, which made the results accesible to be viewed in real time. This is to keep the selection process clean, transparent, objective and free from corruption, collusion and nepotism. Therefore, it is expected that ASN who passed the 2017 selection are the best of the nation's fresh generation.

Meanwhile, in order to increase the capacity of ASN, KemenPAN-RB with the Institute of State Administration (LAN) are transforming the conventional Education and Training for ASN into a Training based on Human Capital Management through the development of ASN Corporate University. This breakthrough training functions all government agencies as learning institutions by combining various educational progressive training systems, such as e-learning, coaching, mentoring and On the Job Training (OJT) (KemenPAN-RB, 2018).

CPNS recruitment that has been implemented in 2017 and the transformation of the Education and Training model that will be developed to increase ASN's capacity are very relevant to the current disruption era. Because: (a) the recruitment system has changed significantly compared to the recruitment of CPNS in previous times which tend to be just for 
show and filled with corruption practices, (b) those recruited are millennials who have several advantages in terms of education, including being cumluade graduates, mastering information technology, being familiar with social media and foreign languages (English), (c) the bureaucratic environment is undergoing changes towards the better future as the result of bureaucratic reform, and (d) a more modern education and training model.

However, there are a number of things that pose challenges in the future, both to the sustainability of the CPNS recruitment system and the capacity and career development of the CPNS themselves.

First, the sustainability of the application of the CPNS recruitment system. This system can be considered relevant to today's demands. The problem is, if there is a change in the presidential position and/or the minister who handles this problem, there is no guarantee that the system will continue. Because based on experience, new leaders' orientation regarding policies will differ from the previous leader.

Second, for CPNS itself. The number of CPNS recruited in 2017 is still small compared to the number of existing ASN, meaning that newcomers will have to adjust to pre-existing environment that has been established with a certain mind-set and culture-set. Will these newcomers be "contaminated" with old patterns or will they be able to become an initiator and agent of change within the institution where he is placed?

A New Era of Indonesian Bureaucracy will be realized as a World Class Bureaucracy, if CPNS recruited from the millennial generation are able to become initiators and agents of change in their respective institutions. If not, then we have to wait longer, until most of the ASN from the old generation are replaced by millennials.

\section{REFERENCES}

1. Balipos.com, 19/05/2017. Renald Kasali Translated "Digital Disruption" at the Second National Coordination Meeting (Rakornas) on Tourism.

2. BBC Indonesia, 21/12/2017. 2017 House of Representative Performance Image: Corruption cases, leadership and failing to meet the target

3. Irfan Islamy, 1997. Principles of State Policies Provision. Jakarta, Bumi Aksara.

4. John Naisbitt, 1994. Global Paradox. The Greater the World Economy, The Greater the Smaller Businesses. Binarupa Aksara, Jakarta.

5. KemmenPANRB, 20/09/2017. Improve the Quality of Public Services with Innovation. (https://menpan.go.id)

6. 27/03/2018. Presidential Press Release on the Lecture at Istora Senayan Jakarta. (https://menpan.go.id)

7. 08/02/2018. 2018 Launching of Public Service Innovation Competition. (https://menpan.go.id)

8. 24/02/2018. 2017 Meeting for Reports on the Evaluation Result and Awards for Public Services 2017. (https://menpan.go.id)

9. Komisi Aparatur Sipil Negara (KASN), 2018. 2017 Performance Report of State Civil Apparatus Commission.

10. Kompas.com, 08/02/2017. Asman the Minister: Indonesia's International Competitiveness Declined from Ranking 37 to 41

11. Kompas.com - 08/02/2017,s.com, 29/12/2017. Throughout 2017, Ombudsman Received 7.999 Public Complaints.

12. Kompas.com, 07/04/2017. Unsuccessful Bureaucratic Reform

13. Monitor.co.id, 29/12/2017. Here are the Challenges Faced by ASN to Reform Bureaucracy

14. Muhamad Imanuddin, 2018. Public Service Innovation Policy (One Agency One Innovation. KemenPANRB, February 7, 2018.

15. Media Indonesia.com 30/04/2018. Jokowi: Bureaucracy's Main Enemy is the Habit of Wasting Time.

16. Kyoung Yul Bae, 2011. M-Government In Korea. (https://unpan1.un.org)

17. Renald Kasali, 2017. Disruption. Nothing is Going to Change If We Do Not Face It, 
Motivation is Not Enough. Competing with the Unseen in Uber Era. Gramedia Pustaka Utama.

18. Renald Kasali, 2017. Redirecting the Understanding on Disruption. Kompas.com, 05/05/2017.

19. Renald Kasali, 2017. Millenials and Disruption. Jawa Post, 16/05/2017.

20. Okezone.com, 28/03/2018. 42 Thousand Regulations Hinder Investment.

21. Tempo.co, 18/04/2018. Jokowi Will Enforce Online Single Submission to be Implemented Sooner.

22. Tempo.co, 22/08/2017. LAN: The Insignificant Bureaucratic Reform of Indonesia

23. Wahyudi Kumorotomo, 2017. Socializing Bureaucratic Reform. JawaPos.com, $15 / 12 / 2017$.

24. Wikipedia.org, 2017. Disruption Innovation

25. World Economic Forum (WEF), 2018. Global Competitiveness Report 2017-2018. (https://www.weforum.org,17/01/2018) 